\title{
PEMBELAJARAN KOLABORATIF PADA MATA PELAJARAN BAHASA INDONESIA DI SMK NEGERI 1 KOTABUMI
}

\author{
Dewi Ratnaningsih*), Septiana **) \\ ratnadewydj@gmail.com, septiana@gmail.com \\ Pendidikan Bahasa dan Sastra Indonesia \\ STKIP Muhammadiyah Kotabumi
}

\begin{abstract}
The problem that will be examined in this article is collaborative learning in Indonesian language subjects at SMK Negeri 1 Kotabumi. The purpose of writing is to describe the application of collaborative learning in Indonesian language subjects at SMK Negeri 1 Kotabumi. Based on the results of reflection, obtained some lessons learned such as: a) collaborative learning tools development resulting in more directed learning plan designs, interactive learning media, and more interesting teaching materials, $b$ ) the application of teaching collaboration between teachers and lecturers makes the evaluation process learning is better covered, c) the use of collaborative learning methods opens space for teachers and lecturers to discuss so as to improve cooperative skills and improve the quality of learning in schools.
\end{abstract}

\section{Keyword: Collaborative Learning, cooperative skills}

\section{A. Pendahuluan}

Peningkatan kualitas pembelajaran menjadi sebuah keharusan dalam dunia pendidikan. Kurang adanya ruang kolaborasi antarguru membuat sistem pengajaran menjadi monoton dan tidak terkontrol. Guru merasa kesulitan untuk melakukan refleksi terhadap pembelajaran ketika tidak memiliki patner/rekan dalam mengajar. Proses kolaborasi dapat dilakukan antarguru atau bahkan antara guru dan dosen. Dosen yang notabene adalah penyelenggara pandidikan di tingkat LPTK menjadi sebuah subjek real untuk dijadikan patner/rekan kolaborasi.
Program Penugasan Dosen ke Sekolah (selanjutnya disingkat PDS) hadir sebagai sebuah solusi untuk hal tersebut. PDS merupakan kegiatan yang memberikan dampak positif bagi LPTK maupun sekolah mitra. PDS merupakan program yang dicanangkan pemerintah untuk meningkatkan kualitas pembelajaran di sekolah maupun di LPTK. Tujuan dilaksankaan program PDS adalah: a) terbentuknya kolaborasi antara guru dan dosen dalam menyusun perangkat pembelajaran, b) terlaksanannya pendampingan pelaksanaan pembelajaran antara guru dan dosen, c) 
merevitasilasai peran LPTK, d) terciptanya kemitraan antara sekolah dan LPTK.

Program PDS memungkinkan terjadinya kolaborasi antara guru dan dosen. Ratnaningsih (2018: 41) mengungkapkan bahwa kemampuan kooperatif/kolaboratif adalah kesanggupan atau kematangan kompetensi dan skill yang digunakan oleh sekelompok orang untuk bekerja secara bersama demi mewujudkan tujuan pembelajaran. Elizabert E. Barkley dalam bukunya Collaborative Learning Techniques mengatakan berkolaborasi berarti bekerja bersama-sama dengan orang lain. Praktek pembelajaran kolaboratif berarti bekerja secara berpasangan atau dalam kelompok kecil untuk mencapai tujuan pembelajaran bersama. Pembelajaran kolaboratif berarti belajar melalui kerja kelompok, bukan belajar dalam kesendirian (Elizabert, 2014: 04). Penerapan pembelajaran kolaboratif tercermin dalam bagan di bawah ini.

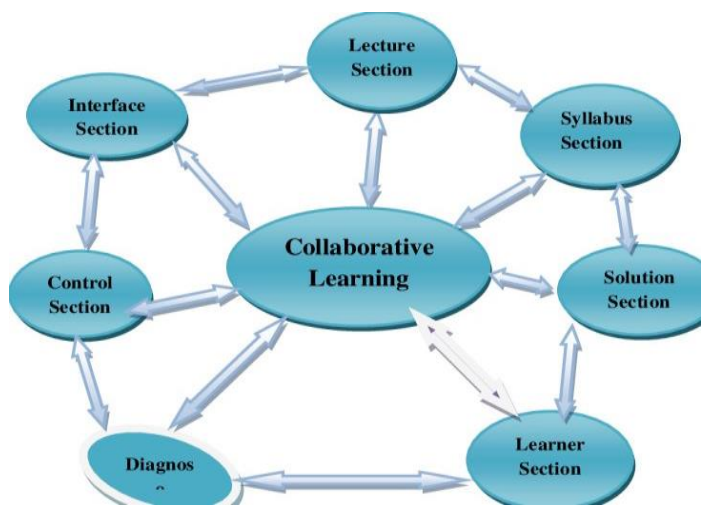

Dalam program PDS, dosen secara langsung ikut terlibat dalam proses belajarmengajar di sekolah. Hal ini dilakukan sebagai upaya untuk menghadirkan pengalaman nyata bagi dosen tentang pembelajaran yang baik dan relevan dengan tuntutan mutu proses pembelajaran di sekolah. Hal tersebut juga dapat menjadi sebuah pengalaman nyata bagi dosen dalam rangka mencetak/menghasilkan mahasiswa lulusan sesuai dengan kebutuhan dunia kerja. Setelah dilakukannya kegiatan mengajar di kelas, pengalaman tersebut menjadi sebuah bahan refleksi ketika mengajar mahasiswa yang nantinya akan menjadi guru di sekolah-sekolah tertentu.

Bentuk kolaborasi antara guru dan dosen dalam kegiatan PDS meliputi: a) kolaborasi penyusunan rencana pelaksanaan pembelajaran (RPP), b) kolaborasi penyusunan media pembelajaran, c) kolaborasi penyusunan bahan ajar yang interaktif, d) kolaborasi penyusunan bahan refleksi pembelajaran sehingga menghasilkan pengalaman baik (best practice). Pelaksanaan kolaborasi tersebut diharapkan menjadi sebuah alat bantu guna terciptanya peningkatan kualitas pembelajaran di sekolah.

Kegiatan kolaborasi antara guru dan dosen dapat berupa berbagi ide/pendapat, kerja sama, diskusi, interaksi, curah gagasan, dan membentuk komunitas belajar. Kegiatan-kegiatan tersebut dapat dilakukan selama guru dan dosen berkolaborasi dalam peningkatan kualitas pembelajaran di sekolah. 


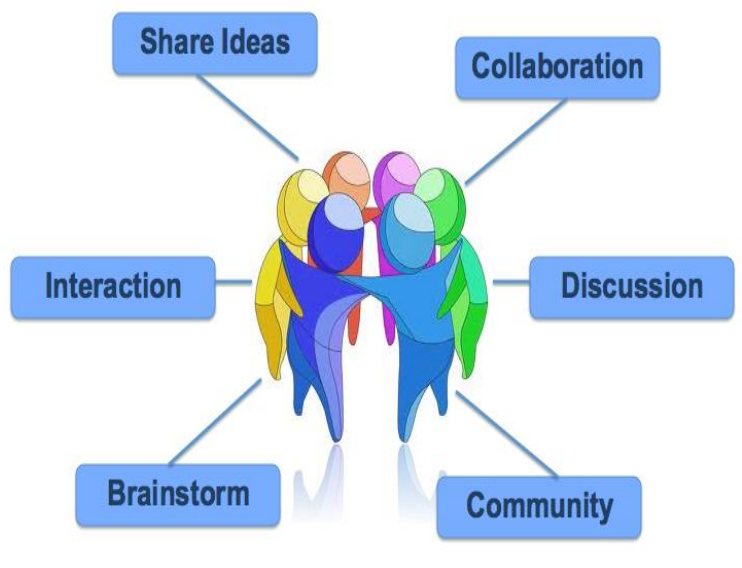

Kolaborasi yang terjadi antara guru dan dosen adalah kolaborasi terkait perangkat pembelajaran. Perangkat pembelajaran adalah salah satu wujud persiapan yang dilakukan oleh guru sebelum mereka melakukan proses pembelajaran. Perangkat pembelajaran adalah sekumpulan media atau sarana yang digunakan oleh guru dan siswa dalam proses pembelajaran di kelas, serangkaian perangkat pembelajaran yang harus dipersiapkan seorang guru dalam menghadapi pembelajaran di kelas (Anonim, 2013). Fathurrohman (2012: 203) menjelaskan bahwa pada dasarnya perangkat pembelajaran mempunyai fungsi untuk mempermudah guru dalam melaksanakan atau mengelola kegiatan pembelajaran yang ada di kelas. Perangkat pembelajaran yang disusun oleh guru antara lain berupa silabus dan RPP, bahan ajar, media pembelajaran dan penilaian. Kolaborasi perangkat pembelajaran meliputi: kolaborasi penyusunan RPP, media ajar, dan bahan ajar.

Kolaborasi penyusunan RPP diawali dari kegiatan mengintepretasi kompetensi dasar yang akan dibahas. Guru dan dosen bertukar pendapat dalam menafsirkan kompetensi dasar yang akan diajarkan kepada siswa di sekolah. Setelah menetapkan materi yang akan diajarkan, guru dan dosen menyusun pendekatan, metode, teknik, dan tatik dalam penyampaian materi yang akan diajarkan. Selanjutany guru dan dosen menyusun langkah-langkah pembelajaran berdasarkan kriteria kurikulum yang berlaku.

Kolaborasi penyususnan media pembelajaran berawal dari pemilihan media interaktif. Penggunaan media pembelajaran interaktif dapat dibantu oleh pihak ketiga yang memahami pengaplikasian dari media pembelajaran interaktif tersebut. Satu di antaranya adalah penggunaan media pembelajaran elektronik (E-Learning). Guru dan dosen dengan dibantu oleh pihak ketiga menyusun pelaksasnaan pembelajaran dengan media E- Learning.

Materi pembelajaran dapat dibedakan menjadi: pengetahuan (knowledge), keterampilan (skill), dan sikap (attitude) (Sanjaya, 2010:142). Kolaborasi penyusunan materi/bahan ajar antara guru dan dosen dilakukan sebagai upaya menghindari sifat monoton terhadap pelaksanaan pembelajaran. Bahan ajar yang 
diberikan lebih disesuaikan dengan karakteristik dan kebiasaan siswa di sekolah. Guru dan dosen berupaya menyusun bersama bahan ajar yang berbeda dari buku paket yang digunakan sehingga siswa lebih tertantang dan tidak merasa jenuh dengan bahan ajar yang biasa saja.

Proses kolaborasi yang dilakukan di atas, dikhususkan pada kolaborasi dalam mata pelajaran Bahasa Indonesia. Mata pelajaran Bahasa Indonesia adalah mata pelajaran wajib yang ada di sekolah. Dalam pembelajaran Bahasa Indonesia, diharapkan siswa memiliki kemampuan berbahasa yang memadai, baik dari aspek menyimak, berbicara, membaca, maupun menulis. Dalam duni kerja, kemahiran dalam keterampilan berbahassa mutlak diperlukan sehingga perbaikan kualitas pembelajaran perlu dilakukan. Hal ini menjadi indikasi perlunya dilakukan kolaborasi pembelajaran dalam mata pelajaran Bahasa Indonesia. Badudu (1993) mengemukakan bahwa pembelajaran bahasa Indonesia di sekolah seharusnya memperhatikan kurikulum, buku, dan guru yang melaksanakan pengajaran. Pembelajaran Bahasa Indonesia di sekolah masih banyak mengalami kendala dalam pelaksanaannya, Belajar pada hakikatnya merupakan aktivitas untuk menghasilkan keterampilan serta adanya proses elaborasi dalam upaya pencarian makna (Pribadi, 2009)
Kolaborasi dalam mata pelajaran Bahasa Indonesia dilakukan di sekolah mitra. Sekolah mitra yang dipilih sebagai tempat pelaksanaan penugasan dosen ke sekolah adalah SMK Negeri 1 Kotabumi. SMK Negeri 1 Kotabumi merupakan sekolah kejuruan yang memiliki akreditasi A. Nilai akreditasi yang memuaskan memungkinkan terjalinnya kolaborasi yang harmonis antara guru dan dosen dalam pelaksanaan pembelajaran. Hal ini yang mendasari pemilihan SMK Negeri 1 Kotabumi sebagai tempat pelaksanaan PDS. Metode yang digunakan dalam penelitian ini adalah metode deskriptif kualitatif. Sugiono (2010:15) adalah metode penelitian yang berlandaskan pada filsafat positivisme, digunakan untuk meneliti pada kondisi obyek yang alamiah, (sebagai lawannya adalah eksperimen) dimana peneliti adalah sebagai instrumen kunci, pengambilan sampel sumber data dilakukan secara purposive dan snowbaal, teknik pengumpulan dengan trianggulasi, analisis data bersifat induktif/kualitatif, dan hasil penelitian kualitatif lebih menekan makna dari pada generalisasi.

\section{B. Pembelajaran Kolaboratif pada} Mata Pelajaran Bahasa Indonesia di SMK Negeri 1 Kotabumi

Implementasi pembelajaran kolaborasi antara guru dan dosen pada mata pelajaran Bahasa Indonesia di SMK Negeri 
1 berlangsung selama 8 pertemuan. Kolaborasi selama 8 pertemuan menghasilkan 2 kompetensi dasar yang dapat diajarkan secara bersama. Kompetensi dasar pertama adalah tentang teks observasi dan yang kedua adalah tentang teks eksposisi. Kompetensi dasar terkait teks laporan observasi dilakukan selama 4 pertemuan. Hal ini seimbang dengan pelaksanaan pembelajaran untuk kompetensi terkait teks eksposisi yang juga 4 pertemuan.

Pada pembelajaran teks observasi, pertemuan pertama, kompetensi dasar yang diajarkan adalah mengidentifikasi laporan hasil observasi yang dipresentasikan dengan lisan dan tulis. Dengan indikator: a) menentukan isi pokok laporan hasil observasi, b) menentukan ciri-ciri kebahasaan dalam teks laporan hasil observasi. Kompetensi dasar pertemuan kedua adalah: Menganalisis isi dan aspek kebahasaan dari minimal dua teks laporan hasil observasi. Dengan Indikator: a) menyusun ringkasan teks laporan hasil observasi berdasarkan struktur, ciri kebahasaan, dan isi teks laporan hasil observasi, b) mempresentasikan hasil ringkasan teks laporan hasil observasi berdasarkan struktur, ciri kebahasaan, dan isi teks laporan hasil observasi. Pada pertemuan ketiga, kompetensi dasar yang diajarkan adalah menginterpretasi isi teks laporan hasil observasi berdasarkan interpretasi baik secara lisan maupun tulis. Dengan Indikator: a) menganalisis kebahasaan teks laporan hasil observasi, b) membenahi kesalahan bahasa dalam teks laporan hasil observasi. Kompetensi dasar pada pertemuan keempat adalah mengkonstruksikan teks laporan dengan memerhatikan isi dan aspek kebahasaan baik lisan maupun tulis. Dengan Indikator: a) melengkapi gagasan pokok dengan gagasan penjelas, b) menyusun teks laporan hasil observasi dengan memerhatikan isi dan kebahasaan

Pada pembelajaran teks eksposisi, kompetensi dasar pada pertemuan pertama dan kedua adalah menganalisis struktur, isi (permasalahan, argumentasi, pengetahuan, dan rekomendasi), kebahasaan teks eksposisi yang didengar dan atau dibaca. Dengan Indikator: a) menentukan struktur, isi teks eksposisi yang dibaca dan didengar, b) menentukan ciri-ciri untuk menulis teks eksposisi dengan topik tertentu, c) menentukan struktur kebahasaan teks eksposisi yang dibaca. Pertemuan ketiga dan keempat adalah menganalisis struktur dan kebahasaan teks eksposisi. Dengan Indikator: a) menemukan ciri-ciri kebahasaan teks eksposisi, b) menganalisis kesalahan kebahasaan teks eksposisi.

Bentuk kolaborasi antara guru dan dosen di SMK Negeri 1 meliputi: kolaborasi penyusunan RPP, media ajar, bahan ajar, dan penilaian pembelajaran. Kolaborasi antara 
guru dan dosen dimulai dari proses perencanaan, pelaksanaan, dan penilaian di setiap akhir pertemuan. Bentuk kolaborasi ini sama halnya seperti bentuk kolaborasi dalam penerapan Lesson Study. Siklus Lesson Study diilustrasikan dalam gambar di bawah ini.

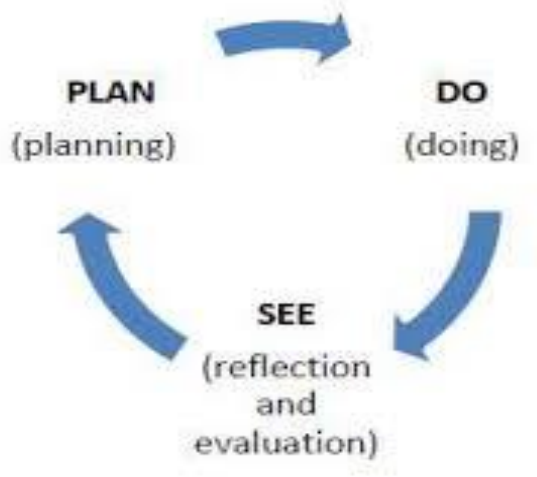

Kolaborasi perencanaan diaplikasikan dalam bentuk kolaborasi penyusunan RPP, kolaborasi penyusunan media ajar dan materi ajar yang akan diberikan. Kolaborasi pelaksanaan diaplikasikan dalam bentuk team teaching atau proses mengajar bersama di dalam kelas. Selanjutnya kolaborasi penilaian diaplikasikan dalam bentuk adanya jurnal refleksi di setiap akhir pertemuan. Guru dan dosen berdiskusi dan mengisi jurnal refleksi untuk melihat keefektifan dan kekurang efektifan pelaksanaan pembelajaran sehingga dapat menjadi bahan refleksi bagi pertemuan selanjutnya.

\section{Kolaborasi Perencanaan}

Kolaborasi perencanaan antara guru dan dosen pada kompetensi dasar yang pertama terkait dengan materi teks laporan observasi. Sementar pada pertemuan kedua terkait materi teks eksposisi. Kolaborasi guru dan dosen yang aterlihat pada kompetensi dasar ini dalah proses menghasilkan atau perumusan RPP menjadi 8 pertemuan. Kolaborasi diawali dengan proses identifikasi materi yang akan dipelajari. Selanjutnya memilih bentuk metode, teknik, dan taktik yang digunakan dalam proses pembelajaran. Perumusan alokasi waktu pelaksanaan juga tak luput dibahas dalam kolaborasi ini.

Hasil kolaborasi perencanaan pada pertemuan pertama terbagi atas: bagian pendahuluan, inti, dan penutup. Pada bagian pendahuluan, tersusun langkah-langkah pembelajaran meliputi: a) siswa melakukan doa/mengaji bersama sebagai bentuk nilai karakter religius, b) siswa diberikan apresepsi terkait materi yang akan dibahas sebagai bentuk nilai karakter rasa ingin tahu. Pada bagian inti, tersusun langkah-langkah pembelajaran meliputi: a) siswa diberikan bahan bacaan sebagai bentuk nilai karakter literasi, b) siswa dibagi menjadi beberapa kelompok. Hal ini dilakukan sebagai bentuk nilai karakter kerjasama, c) siswa berdiskusi untuk menyelesaikan permasalahan sebagai bentuk nilai karakter critical thingking, d) siswa berdiskusi secara kelompok untuk menentukan ciri kebahasaan dari materi yang dibahas. Kegiatan ini dilakukan sebagai bentuk pemberian nilai karakter berupa berpikir kritis, e) siswa sebagai utusan dari setiap kelompok melaporkan hasil kerjanya. Kegiatan ini merupakan kegiatan nilai 
karakter komunikatif. Pada bagian penutup, langkah kegiatan pembelajaran berupa: siswa secara berkelompok menyimpulkan materi yang telah dipelajari. Kegiatan ini merupakan kegiatan yang dilakukan sebagai bentuk nilai karakter kreativitas. Secara umum kolaborasi antara guru dan dosen pada pertemuan pertama sampai kedelapan tidak berbeda jauh. Perbedaan yang terlihat hanya dari pemberian materi/ bahan ajar yang dipelajari.

\section{Kolaborasi Pelaksanaan}

Kolaborasi pelaksanaan merupakan kolaborasi kegiatan belajar-mengajar di kelas yang dilakukan secara bersama-sama antara guru dan dosen. Dalam kolaborasi ini, guru dan dosen berkerja sebagai tim pengajar di kelas. Proses kolaborasi dilakukan dalam bentuk pengajar dan penilai/pengamat. Artinya, ketika salah satu anggota tim bertindak sebagai pengajar, anggota tim yang lain bertindak sebagai penialai dari kegiatan pembelajaran. Hal yang dinilai dari anggota tim penilai adalah melihat kebiasaan siswa ketika dalam proses pembelajaran. Ini dilakukan sebagai catatan pelaksanaan pembelajaran yang akan menjadi bahan refleksi di pertemuan selanjutnya.

Proses koloborasi pelaksanaan pembelajaran pada pertemuan pertama meliputi: a) siswa melakukan doa/mengaji bersama sebagai bentuk nilai karakter religius, b) siswa diberikan apresepsi terkait materi yang akan dibahas sebagai bentuk nilai karakter rasa ingin tahu. a) siswa diberikan bahan bacaan sebagai bentuk nilai karakter literasi, c) siswa dibagi menjadi beberapa kelompok, d) siswa berdiskusi untuk menyelesaikan permasalahan sebagai bentuk nilai karakter critical thingking, e) siswa berdiskusi secara kelompok untuk menentukan ciri kebahasaan dari materi yang dibahas, f) siswa sebagai utusan dari setiap kelompok melaporkan hasil kerjanya. Kegiatan ini merupakan kegiatan nilai karakter komunikatif, g) siswa secara berkelompok menyimpulkan materi yang telah dipelajari. Secara umum kolaborasi antara guru dan dosen pada pertemuan pertama sampai kedelapan tidak berbeda jauh. Perbedaan yang terlihat hanya dari pemberian materi/ bahan ajar yang dipelajari.

\section{Kolaborasi Penilaian}

Bentuk kolaborasi penilaian anatar guru dan dosen berwujud dalam jurnal refleksi. Jurnal refleksi merupakan jurnal yang berisi komponen-komponen yang terjadi dalam kegiatan belajar-mengajar. Proses refleksi dilakukan untuk melihat keseluruhan kegiatan pengajaran di dalam kelas. Anggota tim yang bertindak sebagai penilai/pengamat menyampaikan hasil temuan dari proses pengamatanya. Hasil pengamatan dari anggota tim peniali/pengamat dijadikan bahan untuk merefleksi kegiatan mengajar di dalam kelas. 


\section{Penutup}

Berdasarkan hasil pelaksanaan kolaborasi yang dilakukan antara guru dan dosen, kegiatan PDS banyak memberi manfaat bagi pelaksana kegiatan. Bagi guru: a) kegiatan kolaborasi telah memberikan wawasan terkait pemilihan media pembelajaran yang relevan dengan materi dan lebih menarik, b) memberikan pengetahuan tentang teori-teori kebahasaan yang lebih kompleks. Bagi dosen: a) menambah wawasan tentang dunia persekolahan, b) memeroleh pengalaman tentang karakteristik siswa lebih dekat

\section{DAFTAR RUJUKAN}

Anonim.2013. Pengertian Perangkat Pembelajaran. http://pustaka.pandani.web.id/2013/03/ pengertian -perangkat-pembelajaran.html. Diakses pada tanggal 30 Agustus 2018.

Badudu, J.S. 1993. Cakrawala Bahasa Indonesia. Jakarta: Gramedia.

Elizabert E. Barkley. 2014. Collaborative Learning Techniques. Bandung: Penerbit Nusa Media.

Fathurrohman, Muhammad dan Sulistyorini. 2012. Belajar Pembelajaran Membantu Meningkatkan Mutu Pembelajaran sesuai Standar Nasional. Yogyakarta: Teras .

Pribadi, Benny. 1993. Model Desain Sistem Pembelajaran. Jakrat: Dian Rakyat.

Ratnaningsih, D. (2018). IMPLEMENTASI LESSON STUDY DALAM MATA KULIAH ANALISIS KESALAHAN BERBAHASA UNTUK MENINGKATKAN KEMAMPUAN KOOPERATIF MAHASISWA SEMESTER VII STKIP MUHAMMADIYAH KOTABUMI. Edukasi Lingua Sastra, 16(1), 39-46.

Sanjaya, Wina. 2010. Perencaaan dan Desain Sistem Pembelajaran. Jakarta:Kencana.

Sugiono. 2010. Metode Penelitian Kuantitatif Kualitatif Dan R\&D. Bandung: Alfabeta. 